\title{
Editorial
}

\section{Self and Knowledge}

The contemporary intellectual revival of Muslim societies proposes a profound but problematic relationship between identity and epistemology, and between self and knowledge. I propose to elucidate this relationship and its implications by making a fundamental distinction between self and identity, and showing how there can be many identities but only one self. I begin by inquiring into the meaning of identity symbols such as "Islam" or "Muslim" prior to knowledge. For example, what is the meaning and relationship between identity and knowledge in Islamization of knowledge or Islamic Philosophy? In both types of knowledge, identity is prior to knowledge in an epistemological, as well as an ontological sense.

Ontologically we are suggesting that the existence of Islamic psychology or Islamic philosophy is contingent on the being of an agency such as Islam or Muslims. Epistemologically we are arguing that Islam includes a theory of knowledge, and Islamic principles constitute paradigmatic values from which Islamic psychology or Islamic philosophy can be derived. Clearly, the prefix Islamic gives an identity to knowledge. In other words, there are certain truth claims which derive their legitimacy not because their truth is self-evident or rationally deducible or empirically verifiable, but because they satisfy certain criteria which establishes their identity as Islamic.

The issue of criteria that determine what constitutes knowledge (epistemology) is indeed crucial. The first thing that needs to be resolved is whether these criteria are universally intelligible or are functions of culture/identity and value systems. I would like to posit that in the realms of socially meaningful practices it is possible to have relativistic criteria for determining the validity of social truths. Knowledge about answers to questions such as Is polygyny or homosexuality acceptable? or Are religious rights more important than economic rights? may be determined based on criteria that are located within the corpus of tradition and ethos of a given cultural milieu. This is accomodation of cultural pluralism. But in the realms of science and philosophy, reasoning and empirical evidence alone 
can be the criteria for determining the merit of knowledge claims. If we stray from this position, and succumb to the postmodern seduction of treating all knowledge claims as identity narratives, then there will be no science, no philosophy, and no Truth. There will be nothing universally intelligible. Even God will become a cultural artifact. The Truth of a universal God necessitates the existence of certain universal intelligibles, to the understanding of which science and philosophy are dedicated.

Many Muslim thinkers reject the proposition that knowledge about things in this world can be produced through reason and/or empirical observations alone and seek a missing Islamic ingredient that would interact with observed data and reason to produce Islamic knowledge whose veracity would be beyond doubt. I think this claim is based on the false premise that Western knowledge, especially social science, is purely based on reason and/or observation. And since the current outcome of this knowledge is an immoral West, Muslim thinkers tend to reject reason and observation as sole criteria of determining the merit of knowledge claims, and search for some magical Islamic ingredient that would sanitize (Islamize) reason and observation.

We must recognize that where reason and observation rule as in natural science, the West does produce significant results. But when it comes to political, social, economic, and moral issues, the many failures of the present West are a testimony to the fact that its triumphs in the natural sciences are not replicated in the social sciences. It is my conviction that such is the case because in the social arena, Western scholars too allow their identity (based on secular humanism and anthropocentrism) to corrupt their understanding. They allow their politics to implicate their social sciences. Therefore, we must be very careful before we allow Western discourses the claim that they are based purely on reason and/or observation.

Consider for a moment the methodology of the Qur'an. It does not ask us to believe in itself or in God because it says so. The Qur'an is full of exhortations to think and reflect upon the signs of God in text as well as in nature. It asks us to look at the planets and reflect upon their laws of motion. It recommends that we know God and understand his laws through observation of the order in nature. The Qur'an demands that we use our 'aql (reason/intellect) to reach the truth. It also expects us to infer lessons from history and from the experiences of civilizations that preceded us (Ilm-ulSunan). In some places God challenges us to bring forward proof if we disagree with him. The mood in the Qur'an is completely scientific and deeply 
amenable to the idea of Truth as verifiable and intelligible through reason and observation. The Muslim faith is not a belief in things unintelligible to reason or science. It is a faith, which is more like considered judgment. Indeed, it would be un-Qur'anic to underestimate the importance of reason and observation in knowing. A Muslim is not a just a believing being but also a knowing being. Indeed, the "belief" is a function of knowledge.

Let us now return to Islamic social science and Islamic philosophy. When we use identity symbols prior to knowledge, are we stating that these types of knowledge are not subject to universal verification? If external verification of any type, empirical or rational is not the criteria for determining the merit of knowledge claims, then does not knowledge become ideology? It is like saying that in order to see the truth in Islamic philosophy or Islamic psychology you must believe in Islam. What then is the difference between philosophy and theology or social science and theology?

Before we explore the relationship between identity and knowledge let us scrutinize the idea of identity itself. Identity is, in many ways, our direct or mediated understanding of who we are. Who we are can be understood in individual as well as collective terms. When we indicate to ourselves who we are, and this is usually accomplished by attributing to ourselves meanings that give us "distinctions of worth," we are creating a self-identity. When we indicate to others who we are, this is usually accomplished by emphasizing difference, we create a strategic identity. When we indicate ourselves to others but seek to emphasize commonality (identity) and not difference, we create collective identities.

There are at least three levels at which identity is understood in the discussion above. Self-identity results when the subject and object are identical. This is knowledge of who we are that is unmediated by strategic context and other existing identities. While all other forms of identities are constructed, self-identity is essential. Thus, when a person claims to be an Indian-American-Sunni-Hanafi Muslim, the person claims to owe allegiance to multiple identities. This person may also choose to be only an Indian, or only an American, or only a Muslim. Indeed, under various circumstances the person may consciously choose to emphasize one identity over another. Nevertheless, whatever identity the person may choose to identify with at any given time, his or her self-knowledge remains unchanged. Thus, regardless of what the person chooses to introduce him or herself as, the person's "self-identity," the "I" that speaks to the I is the same. 
All other identities are really strategic, contextual, and contingent. They are dependent on the "other" in contrast to whom the self is defined. For example, let us consider the following identities. An Arab essentially means that the subject is not a Persian or a European or anything else (ajami). When an Arab-Christian says he is an Arab-Christian he is choosing to particularly distinguish himself from Arab-Muslims. Thus, when one asserts self-identity, one simultaneously distances oneself from "other" identities. The construction of identity is a consequence of emphasizing difference. Collective identities are the result of the opposite process. Collective identities undermine difference and emphasize identity.

These types of identities are instrumental and strategic because they are a function of how the other is perceived or positioned. For example, if an Arab Christian seeks to identify with a European Christian, he emphasizes identity and suggests, "We are both Christians," to express collective identity. If, however, he chooses to distance himself from the European Christian he emphasizes difference and says, "I am an Arab and the other is not."

Based upon the above discussion, I would like to argue that, while we are capable of possessing multiple identities, we have only one self-the "I" that I am always aware of, no matter what identity I choose to deploy in a given sociopolitical context. From the discussion above we have also learned that identities are defined in contrast to others. But how is self defined? The essential self, that which is distinct from constructed identities, the "I" that one refers to in knowledge of the self, is recognized in opposition to God who is the other in this equation. I think that when I assert "I," I am basically stating that I am not God. Thus in a very profound sense, the assertion of the primordial self is the accomplishment of two acts of truth. When we claim that I exist and I have a self, I am actually asserting that I am not God, and that there is a God/Creator whose creation I am. Since God is eternal, unchanging and absolute, the self that is posited in contradistinction to God is also eternal, unchanging and absolute. In a beautiful way the relationship between the self and its creator at once includes identity as well as difference. To assert that the self cannot exist without the other (God) is the profoundest expression of identity, but to recognize that the self and the other belong to different ontological categories, creator and created, is to recognize a profound and unparalleled difference.

The postmodern dilemma of order in a world of multiple identities is resolvable by recognizing that while there are many identities, there is only 
one self. Identities are constructed through historical and cultural signifiers of meanings, with symbols and through shared values. Identities are always contextual, constructed, and relative. But the self is absolute, essential, and eternal. Identities are a product of "horizontal relationships" of identity and difference, and the self is the consequence of a "vertical relationship," which simultaneously posits identity as well as difference. Multiple identities are possible because multiple others are possible. There are, in a manner of speaking, as many identities as there are relationships between self and other. But only one self is possible because there is only one other (God). The primordial self is the humanized reflection of the exclusive singularity of God. Since there is only one God, there can be only one other in the vertical dimension and therefore only one true self. Therefore, in the horizontal realm I can be Muslim, sunni, younger, liberal, and many more; in the vertical sense, I can only be 'abd Allah ('abd is the opposite of God usually translated as servant or slave).

Having discussed the distinctions between the divinely constituted self and socially constructed identities, I now propose to explore the relationship between knowledge and self/identity. Let us, for example, consider the claim advanced by many philosophers, particularly Dr. Seyyed Hossein Nasr, that there is such a thing as Islamic philosophy. This claim places identity prior to philosophy. It is not a product of philosophy. For to claim an Islamic philosophy, is to assert the existence of an Islamic self which philosophizes without implicating the self (current discourses on Islamization of thought do not distinguish between self and identity as I have in this discussion). That is, self and philosophy are forever separated. Now we are forced to conceptualize self-reflection and reflection as two mutually exclusive processes. If the self is not a product of philosophical reflection then what is self-reflection? We are forced to imagine a metaphilosophy of the self, prior to Islamic philosophy.

Thus when knowledge is a function of a self or an identity and the process of knowing does not implicate the self or the identity itself, then we have a knowledge form that is subordinate to the self/identity. This is not knowledge of things as they are but is knowledge of things as they relate to the self or identity. An excellent example of this type of knowledge is the knowledge of Islam that is produced in West by orientalists. The orientalists' discourse is not knowledge about Islam as it is. It is knowledge of Islam as it relates to the West. This discourse in understanding Islam seeks 
to realize Western identity and its interests while protecting it from potential influence from Islam.

Similarly, when we advance knowledge forms such as Islamic psychology or Islamic philosophy, these discourses primarily defend the self/identity of Islam rather than understand things as they are. It is quite possible that our knowledge of things may reshape our understanding of our self/identity. For if the West were to understand Islam as it is then it would simultaneously change their understanding of who they are. The most obvious change that I can envision is that the West would think of itself as an Abrahamic civilization rather than a Judeo-Christian one if its knowledge of Islam were more than strategic. The fear that knowledge, unsubordinated to identity, will transform us, compels us to advance discourses such as Islamic philosophy or Islamic psychology. We are guarding who we are when we think, and therefore our thoughts are limited by our conceptions of ourselves.

I believe that if we allow our identity, which is horizontally constituted with respects to "others" (such as the West) to shape our discourses, then the knowledge we produce will only serve the purpose of defending our identity. The constant critique of Western discourses and the unceasing desire to distinguish between Western and Islamic social sciences or between Western and Islamic philosophies, is basically a manifestation of our politics - to maintain the difference between us and them. And because identities are imaginary, knowledge emerging from these identities too is imaginary.

But while identities are imaginary, the self is real and unchanging because it emerges and derives its meanings from the absolute. Knowledge, which is produced to defend this self, will like it to be real. In conclusion, since what we know is so profoundly linked with who we are, we better know who we are in order that we may know. We must be very careful to separate our identities from our self, for identities not only corrupt our self but also influence what we can know. We can run the risk of allowing our identities to impact our politics but we must not allow them to implicate our epistemology.

We must learn to eschew the influence of identities and search for knowledge based upon an understanding of the primordial self. This knowledge is in many ways the knowledge that speaks about the nature of the divine and the nature of the self and the relationship between the two. It is a product of the interaction of our 'aql (reason/intellection) with revelation and 
nature. It is like simultaneously reading two books (revealed and created) authored by the divine being. Both are mere accumulation of His ayahs (signs). Indeed, the keys to understanding the secrets of one book may be found in the other. The simultaneous reading will open more locks to the truth than one can imagine. The knowledge that will emerge from this simultaneous reading is the knowledge that we seek in endeavors like Islamic philosophy and Islamic social science A knowledge that is grounded in the recognition of the primordial self.

What does this relationship between self and knowledge mean to the intellectual revival of the Islamic civilization? First of all, it deconstructs the very idea of Islamic civilization as we understand it today. Islamic civilization as we understand it was not an intended consequence of a systematic methodology. Nor was it premised on a given Islamic science or Islamic epistemology. It slowly emerged through a historical process, which was a consequence of a people's struggle to realize the meaning of their self in social context. What we call Islamic civilization today got its identity much after Islam's decline. In its own time it was a manifestation of itself. The present discussion begs the question of whether the primordial self exists only in the individual state or also in the collective form? We shall defer that discussion for another occasion. However, at the moment we must keep in mind that the idea of a collective self is essential to any discussion of an Islamic or any other civilization.

Finally, I would like to suggest that our efforts to reconstruct a glorious Islamic civilization should not be premised upon our understanding of its identity in history. We must on the contrary discover it inside us, in the meaning of the self. Therefore, we must reestablish our connection with the divine and enable the vertical constitution of the self. We must escape the confines of our horizontal relationships to free knowledge from ideology, and epistemology from identity. Only then will a civilization emerge that will embody the Qur'anic verse, nürun 'ala nūr (light upon light), to which the identity, Islamic civilization, maybe appropriately attributed.

M. A. Muqtedar Khan Managing Editor, AJISS General Secretary Association of Muslim Social Scientists 